INTERNATIONAL JOURNAL OF MULTIDISCIPLINARY RESEARCH AND ANALySis

ISSN (print): 2643-9840, ISSN (online): 2643-9875

Volume 04 Issue 05 May 2021

DOI: 10.47191/ijmra/v4-i5-27, Impact Factor: 6.072

Page No. $-670-673$

\title{
Some Aspects of Illegal Migration in the Legislation of Uzbekistan and the Participation of the Prosecutor in the Trial Regarding This Category of Criminal Cases
}

\author{
Mukhtaram Ziyodullaevna Radjapova \\ Head of the Department the Academy of the General Prosecutor's Office
}

ABSTRACT: The article highlights the concept of illegal migration, presents a brief description of the commission of illegal travel abroad and the liability for such acts established by the legislation of Uzbekistan. In addition, the author discusses the issues that should be brought to the attention of the prosecutor involved in the trial of this category of criminal cases, the liability for such actions and the prevention of illegal migration.

KEYWORDS: migration, official migrants, illegal migrants, migrants in need of protection, state border area, abroad, citizens, foreign citizens, stateless persons

\section{INTRODUCTION}

International migration of population is a fact, which has already become the part of contemporary life. We could state without hesitation that, in today's globalization process there is no country in the world that has not been affected by migration issues.

The issue of migration is becoming increasingly relevant due to its scale, causes and consequences.

Pursuant to Article 28 of the Constitution of the Republic of Uzbekistan, 'a citizen of the Republic of Uzbekistan shall have the right to freedom of movement on the territory of the Republic, as well as to free entry to and exit from it'.

Article 22 specifies that 'The Republic of Uzbekistan shall guarantee legal defense and protection to all its citizens both on the territory of the Republic of Uzbekistan and abroad' [1].

The term migration is derived from the Latin word 'migrans', which means moving of a person from one region to another for permanent or temporary residence.

There could be different reasons for moving from one country to another.

"Today, our compatriots are working abroad not only in black labor, but also in the spheres of science, banking and finance, information and communication technologies. Given this situation, it should be noted that the attitude to our citizens working abroad legally, and studying abroad has today changed dramatically. The government of Uzbekistan will henceforth protect the rights and interests of its citizens in all respects, no matter where (which country) they are", said the President of Uzbekistan Sh. Mirziyoyev in his speech at the solemn ceremony dedicated to the 25th anniversary of the adoption of the Constitution of Uzbekistan[2].

Over the past few years, a number of legal documents have been adopted in our country to prevent illegal migration and ensure the protection of the rights and legitimate interests of our citizens working abroad.

The Decree No 4829 of the President (dated September 15, 2020) “On measures to introduce a system of safe, orderly and legal labor migration" [3] is of particular importance in preventing illegal migration.

It should be emphasized that illegal exit from the territory of the country in violation of relevant law is one of the most critical problems in the field of migration.

The migration issue is also serious in terms of 1 ) the causes and consequences of illegal migration are linked to a number of other crimes, and 2) it leads to the violation of the rights and interests of citizens who have left the country illegally.

The head of our state Sh.M.Mirziyoev in his speech at the solemn ceremony dedicated to the International Women's Day on March 7, 2018, mentioned illegal migration being in the list of the serious crimes and said: "Today, international terrorism, extremism, drug trafficking, illegal migration, human trafficking, environmental problems are of great concern to all mankind, 
Some Aspects of Illegal Migration in the Legislation of Uzbekistan and the Participation of the Prosecutor in the Trial Regarding This Category of Criminal Cases

including us. In such a difficult environment, maintaining peace and tranquility in our country and region is becoming more important than ever"[4].

We can reflect on the following categories of migrants:

- official migrants. They intend to move from one country of permanent residence or citizenship to another country and act in accordance with the relevant permit of that country;

- illegal migrants without proper documents. Such migrants are those who have entered the country illegally or are staying in the country even though their residence permit has expired;

- other migrants in need of protection (for example, persons who entered the country or were denied asylum without proper registration documents for the right to political asylum).

The article "Criminal-legal and criminological aspects of migration" by PhD in Law A.N.Shkilev focuses on the concept of migration: "The concept of migration means the territorial movement of the population in space due to socio-economic, political-legal and national-demographic reasons".

A.N.Shkilev points out that, based on the legal status of migrants, they can be divided into legal and illegal migrants[5].

When it comes to the prevention of illegal migration, it is important to reflect on the relevant norms (liability for illegal exit from the territory of Uzbekistan) of the current Administrative Responsibility Code and Criminal Code of the Republic of Uzbekistan.

Pursuant to the Article 226 (part one) of the Code of Administrative Responsibility of Uzbekistan, there is an administrative liability for violation of established procedure of applying for preparing travel documents abroad. For such actions citizens may be fined in the amount of three to five times the basic calculation amount, in line with confiscation of illegally prepared documents.

According to the second part of the given article, if it is an official who commits the cited offence (preparation of documents for travel abroad in violation of the established procedure), $s /$ he shall be fined from seven to ten times the basic calculation amount.

In accordance with paragraph 3 of the Regulation "On the procedure for exit of citizens of Uzbekistan from the county" [6] (this Regulation is confirmed by the Presidential Decree No. PP-4079[6] dated 26.12.2018, "On additional measures for the creation of a system of registration and issuance of biometric passports for travel abroad of citizens of the Republic of Uzbekistan and the modernization of the biometric passport system of the Republic of Uzbekistan"), the citizens of the Republic of Uzbekistan, except for the restrictions established by the legislation, are entitled to freely travel abroad and enter the Republic of Uzbekistan in the manner prescribed by this Regulation.

Based on the paragraph 6 of the Regulation, the biometric passport for travel abroad is the property of the Republic of Uzbekistan, the owner of which is under the protection of the Republic of Uzbekistan.

The violation of the established procedure for the issuance of documents for travel abroad, established by the above regulations is the object of Article 226 of the Code of Administrative Responsibility of Uzbekistan.

Going abroad or entering the territory illegally is criminalized by the current Criminal Code (Article 223) of Uzbekistan [7]. Based on the disposition of this norm, actions such as going abroad or entering Uzbekistan or crossing the border in violation of the established procedure shall entail criminal liability.

When considering such criminal cases in courts, in accordance with Article 409[8] of the Criminal Procedure Code of Uzbekistan, the prosecutor supporting a public prosecution is supposed to refer to a number of normative legal acts in order to determine whether the criminal conduct was properly qualified.

In particular, for the correct qualification of this crime, it is necessary to define the concept of a certain territory and its scope.

The Criminal Code defines the meaning of the word territory in Article 223. According to it, the term "territory" refers to the territory of the country, that is, the territory of the Republic of Uzbekistan.

Based on the Wikipedia, a country is a territory which has national, climatic, cultural, historical, or political borders [9].

Article 3 of the Law of Uzbekistan "On State Border" specifies that the State Border of the country consists of a line defining the territory of the Republic of Uzbekistan (land, water, ground, air) and a vertical level passing through this line [10].

Article 15 of this Law defines the scope of violators of the State Border. This norm should be taken into account in determining the scope of the subjects who committ criminal acts. In particular, the followings are considered violators of the state border:

- Persons who have crossed or are attempting to cross the state border by any means at any place other than the State border checkpoints or persons who have crossed or are attempting to cross the border by any means through checkpoints, but in violation of the rules of crossing the border;

- Persons who have boarded or are trying to board (from the Republic of Uzbekistan) the vehicles going abroad with the 
Some Aspects of Illegal Migration in the Legislation of Uzbekistan and the Participation of the Prosecutor in the Trial Regarding This Category of Criminal Cases

purpose of illegal exit from the county.

Illegal exit from the territory of Uzbekistan may be carried out by a person crossing the state border by vehicle or crossing it on foot.

Crossing the state border in violation of the established procedure, for example, crossing via hidden/secret routes or without proper permission, that is, crossing the border in the absence of actual documents authorizing the crossing, proves that the person has committed an illegal entry or exit.

In addition, crossing the state border using forged documents, using expired documents, using documents issued in the name of another person, and using incorrectly executed documents shall be considered as crossing the state border without proper permission.

According to the disposition of this norm, illegal exit of a person from the territory of the country or illegal entry into the territory of the country and attempts to illegally cross the border must be proven in the context of a criminal case.

Providing a person commits an act of illegal exit or illegal entry into the country together with the crime of crossing the customs border in violation of the established procedure for goods and means of transport, his/her actions shall be qualified as a set of crimes.

The Resolution No. 18 of the Plenum of the Supreme Court of the Republic of Uzbekistan (dated September 6, 2013) "On judicial practice in cases of violation of customs legislation and smuggling" focus on this issue. In this regard, Paragraph 12 reads as follows: "Provided a person commits a crime of illegal exit or entry into the Republic of Uzbekistan, in addition to violation of customs legislation, his actions are qualified by a set of crimes provided for in Articles 182 and 223 of the Criminal Code" [11].

It should be emphasized that based on the CIS Member-States Cooperation to Counteract Illegal Migration Concept (approved by the Council of Heads of the CIS member states on September 16, 2004) the concept of illegal migration includes actions such as entering the territory of a CIS member state and being in that state in violation of the legislation of that state.

Article 2 of the Concept (basic concepts) defines the term illegal migrant as follows: - Citizen of the CIS member state, entering into, exiting from, being on the territory of third countries in violation of the established rules, and entry into, exit from, being of stateless persons on the territory of another CIS state in violation of the established rules [12].

According to Article 223 (part one) of the Criminal Code, exit from or entry in the Republic of Uzbekistan, or crossing the state border, which violate the duly set procedures - shall be punished with fine from two hundred to one four hundred times the basic calculation amount, or restriction of liberty from three to five years or imprisonment from three to five years.

The same actions committed: a) by breaking the border lines; b) by previous concert by a group of individuals; c) by a repeat or dangerous recidivist; d) by an official whose exit requires a special approval; e) by a person whose right to enter the Republic of Uzbekistan is restricted in accordance with the established procedure, shall be punished with imprisonment from five to ten years (part two of Article 223).

Foreign nationals and stateless persons, who arrived in Uzbekistan without due formalization of entry documents in order to exercise the right to political asylum envisaged by the Constitution of the Republic of Uzbekistan, shall be excused from liability (part three of Article 223).

As an equal member of the CIS, Uzbekistan is a party to multilateral and bilateral agreements between the member states of the Commonwealth on labor migration and labor relations.

Particularly, Agreements "On protection of labor activity and rights of migrant workers of the Republic of Uzbekistan in the Russian Federation and migrant workers of the Russian Federation in the Republic of Uzbekistan" [13] and "On Combating Illegal Migration" [13] (concluded between the Governments of Uzbekistan and Russia on July 4, 2007) has been serving to help the regulation of labor migration processes, ensure the protection of social, economic and other rights of migrants and to create favorable conditions for the free movement of labor between the two countries.

It should be noted that on August 12, 2020, Uzbekistan became a member of another document within the CIS.

This was Protocol amending the Agreement (of November 13,1992) on the establishment of the Consultative Council of the Commonwealth of Independent States on labor, migration and social protection of October 28, 2016 in Minsk. According to it, the Ministry of Employment and Labor Relations of the Republic of Uzbekistan has been designated as the competent authority responsible for the implementation of this international agreement, and a number of ministries have been assigned specific tasks.

Without doubt, the reforms in this regard and adopted legal acts in Uzbekistan in recent years are aimed at ensuring the effective protection of the rights of our citizens who go abroad to study and work, and definitely shall facilitate to prevent illegal migration. 
Some Aspects of Illegal Migration in the Legislation of Uzbekistan and the Participation of the Prosecutor in the Trial Regarding This Category of Criminal Cases

\section{REFERENCES}

1) "Bulletin of the Supreme Council of the Republic of Uzbekistan", 1993, No. 1, Article 4

2) The consent of our people is the highest value given to our activities. T. Uzbekistan - 2018 Volume 2 p.38

3) National database of the legislation, 16.09.2020, No. 07/20/4829/1281

4) The consent of our people is the highest value given to our activities. T. Uzbekistan - 2018 Volume 2 pp. $472-$ 473

5) Journal Modern problems of science and education. 2013-No. 3

6) National Database of Legislation (www.lex.uz) December 27, 2018

7) https//www lex.uz /acts/

8) Lex.uz/docs Criminal Procedure Code of the Republic of Uzbekistan

9) https://uz.m.wikipedia.org

10) Lex.uz/docs Law of the Republic of Uzbekistan "On State Border"

11) Lex.uz/docs Decision of the Plenum of the Supreme Court of the Republic of Uzbekistan dated September 6, 2013

12) Cis.minsk.by/page/428

13) Collection of international agreements of the Republic of Uzbekistan 2007. Number 4

14) Nodirov, D. (2020). ENSURING THE SUPREMACY OF LAW IN THE DEVELOPMENT OF AGRICULTURE IN UZBEKISTAN. European Journal of Molecular \& Clinical Medicine, 7(8), 1414-1418.

15) Nodirov, D. (2020). Issues of improving prosecutorial control over the implementation of legislation in the field of agriculture and food. European Journal of Molecular \& Clinical Medicine, 7(2), 663-670. 